\title{
Efficiency of cationic gemini surfactants with 3- azamethylpentamethylene spacer as corrosion inhibitors for stainless steel in hydrochloric acid
} DOI:

10.1016/j.molliq.2017.09.103

\author{
Document Version \\ Accepted author manuscript
}

Link to publication record in Manchester Research Explorer

Citation for published version (APA):

Kaczerewska, O., Leiva-Garcia, R., Akid, R., \& Brycki, B. (2017). Efficiency of cationic gemini surfactants with 3azamethylpentamethylene spacer as corrosion inhibitors for stainless steel in hydrochloric acid. Journal of Molecular Liquids, 247, 6-13. https://doi.org/10.1016/j.molliq.2017.09.103

\section{Published in:}

Journal of Molecular Liquids

\section{Citing this paper}

Please note that where the full-text provided on Manchester Research Explorer is the Author Accepted Manuscript or Proof version this may differ from the final Published version. If citing, it is advised that you check and use the publisher's definitive version.

\section{General rights}

Copyright and moral rights for the publications made accessible in the Research Explorer are retained by the authors and/or other copyright owners and it is a condition of accessing publications that users recognise and abide by the legal requirements associated with these rights.

\section{Takedown policy}

If you believe that this document breaches copyright please refer to the University of Manchester's Takedown Procedures [http://man.ac.uk/04Y6Bo] or contact uml.scholarlycommunications@manchester.ac.uk providing relevant details, so we can investigate your claim.

\section{OPEN ACCESS}




\section{Accepted Manuscript}

Efficiency of cationic gemini surfactants with 3-azamethylpentamethylene spacer as corrosion inhibitors for stainless steel in hydrochloric acid

O. Kaczerewska, R. Leiva-Garcia, R. Akid, B. Brycki

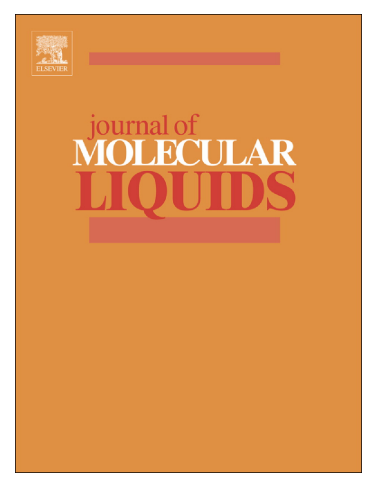

PII:

S0167-7322(17)31599-4

DOI: doi:10.1016/j.molliq.2017.09.103

Reference: MOLLIQ 7940

To appear in: Journal of Molecular Liquids

Received date: 13 April 2017

Revised date: 9 August 2017

Accepted date: 23 September 2017

Please cite this article as: O. Kaczerewska, R. Leiva-Garcia, R. Akid, B. Brycki , Efficiency of cationic gemini surfactants with 3-azamethylpentamethylene spacer as corrosion inhibitors for stainless steel in hydrochloric acid. The address for the corresponding author was captured as affiliation for all authors. Please check if appropriate. Molliq(2017), doi:10.1016/j.molliq.2017.09.103

This is a PDF file of an unedited manuscript that has been accepted for publication. As a service to our customers we are providing this early version of the manuscript. The manuscript will undergo copyediting, typesetting, and review of the resulting proof before it is published in its final form. Please note that during the production process errors may be discovered which could affect the content, and all legal disclaimers that apply to the journal pertain. 


\title{
Efficiency of cationic gemini surfactants with 3-azamethylpentamethylene spacer as corrosion inhibitors for stainless steel in hydrochloric acid
}

\author{
O. Kaczerewska ${ }^{1,2^{*}}$, R. Leiva-Garcia ${ }^{2}$, R. Akid $^{2}$, B. Brycki ${ }^{1}$ \\ ${ }^{1}$ Laboratory of Microbiocides Chemistry, Faculty of Chemistry, Adam Mickiewicz University \\ in Poznań, Umultowska 89b, 61-614 Poznań, Poland \\ ${ }^{2}$ School of Materials, University of Manchester, Manchester, M139PL, UK \\ *corresponding author \\ e-mail address: olga.kaczerewska@wp.pl
}

\begin{abstract}
The corrosion inhibition efficacy of two cationic gemini surfactants with 3azamethylpentamethylene spacer on AISI 304 stainless steel in $3 \mathrm{M} \mathrm{HCl}$ was investigated by polarisation measurements and electrochemical impedance spectroscopy (EIS). Following corrosion testing, the surface of stainless steel samples was studied by scanning electron microscopy (SEM). The results showed that the effectiveness of corrosion inhibition were up to $95 \%$ depending on the $\mathrm{C}$-chain length and the gemini surfactant concentration. The inhibitive action is due to an adsorption of inhibitor molecules onto the metal surface following a Langmuir adsorption isotherm model. The variation in the cathodic and anodic branches reveals that the surfactants tested act as mixed-type inhibitors. The highest inhibition efficiency was reached around the values of the critical micelle concentration. The results obtained from both polarisation and EIS measurements are in a good agreement.
\end{abstract}

\section{Keywords}

Corrosion inhibitors, gemini surfactants, potentiodynamic, EIS

1. Introduction

Cationic gemini surfactants are an interesting class of chemical compounds. These dimeric surfactants consist of two monomeric moieties linked by a spacer [1], which can be flexible (eg. polymethylene groups) or rigid (eg. benzene ring) [2]. Interest in gemini surfactants arises from their superior aggregation, surface and biological properties compared to conventional analogues. Dicationic compounds strongly reduce the surface tension [3], 
exhibit lower critical micelle concentration (CMC) values [4] and so much higher biological activity [5]. In terms of concentration, they are about one to two orders of magnitude more efficient compared to conventional surfactants [1,6,7]. Moreover, from an environmental point of view, dicationic compounds are less hazardous than monomeric ones [8]. Due to their excellent properties, gemini surfactants can have many potential industrial applications such as cleaning agents and detergents, biocides, preservatives and solubilisation agents in textile dying [7,9-14]. They can be also applied in nanotechnology as gene delivery agents and supramolecular solvents [15-17]. Recently, greater attention has been paid to the use of gemini surfactants as corrosion inhibitors (CIs) for metals, especially in acidic environments [18-24]. The mechanism of corrosion inhibition is based on the adsorption of surfactant molecules onto the metal surface, replacing water molecules and forming a protective film $[25,26]$. The process is physicochemical. The electrostatic interactions between positively charged nitrogen atoms and negatively charged metal surface is related to physisorption [27]. Chemisorption is connected with donor-acceptor interactions [28]. Adsorption is favourable due to the presence of electron-rich structures such us heteroatoms with unbonded electrons $(\mathrm{N}, \mathrm{O}, \mathrm{S}, \mathrm{P})[29,30]$ and $\pi$ electrons (benzene rings, multiple bonds) [22,24] as these can share electrons with the free $d$-orbitals of metals [27].

A key parameter for using surfactants as corrosion inhibitors is the critical micelle concentration value (CMC), a value related to the surfactant concentration when molecules start forming aggregates (micelles). Typically at this value, surfactants first adsorb onto an interface (air-water, water-metal surface) and then form micelles or multilayers. The CMC value depends on the chemical structure of the gemini surfactants. Increasing the length of the alkyl chain [31,32], the spacer [33] and the number of quaternary nitrogen atoms [34,35] decrease the CMC values. Also, heteroatoms or multiple bonds changes the aggregation properties of the molecules [7,36]. Therefore, the efficacy of corrosion inhibition can be influenced by a reasonable modification of gemini surfactant structure [22].

Corrosion in acidic environments is a serious problem in petrochemical, marine or chemical production [37,38] due to the use of hydrochloric acid solutions [29] for cleaning, pickling, descaling or oil well acidification [26,39]. Every year corrosion results in huge economic losses, decreasing operation efficiency and increasing the risk of accidents [40].

Stainless steels are widely used in industry as construction materials for piping, tanks and vessels etc, $[25,38]$ because of their good corrosion resistance due to the presence of a passive layer (mixed oxide layer) on its surface. Despite the good properties of stainless steel, corrosion may occur and the use of protection systems is needed [41]. One option would be 
the use of cationic gemini surfactants, however, there is a lack of information on their performance as corrosion inhibitors for stainless steels.

Therefore, in this paper, the efficiency of cationic gemini surfactants with a 3-azamethyl pentamethylene spacer as corrosion inhibitors of stainless steel in $3 \mathrm{M}$ hydrochloric acid is studied by electrochemical techniques and surface morphology analysis by scanning electron microscopy (SEM).

2. Materials and Experimental Techniques

2.1. Cationic surfactants

Gemini surfactants, 3-azamethyl-1,5-pentamethylene-bis( $N$-dodecyl- $N, N$-dimethylammonium bromide $\quad(3 \mathrm{~N}-12) \quad$ and 3 -azamethyl-1,5-pentamethylene-bis $(N$-octadecyl- $N, N$ dimethylammonium bromide) (3N-18) have been prepared by a method previously described in the literature $[7,42]$. The chemical structure of the synthesised surfactants is presented in Figure 1.

2.2.Stainless steel

The working electrode was made of stainless steel (AISI 304). The chemical composition of the working electrode in (weight \%) being: $\mathrm{Cr} 17-20, \mathrm{Mn}<2$, Ni 8-11, C<0.08, Fe balance.

\subsection{Electrolytes}

The test electrolyte, $3 \mathrm{M} \mathrm{HCl}$ was prepared by dilution of analytical grade $\mathrm{HCl}(32 \%)$ with deionised water. Solutions with different concentrations of inhibitors were prepared from the stock solution of $3 \mathrm{M} \mathrm{HCl}$. The range of concentrations for the compound with twelve carbon atoms in the alkyl chain was: $0.1-2 \mathrm{mM}$ and for the one with eighteen carbon atoms was 0.005-0.1 mM. The concentration chosen were based upon CMC values of the surfactants previously determined by the authors using conductometry methods [43]: $1.06 \mathrm{mM}$ for $3 \mathrm{~N}-12$ and $0.076 \mathrm{mM}$ for $3 \mathrm{~N}-18$. All experiments were carried out at room temperature in a naturally aerated test solution.

\subsection{Electrochemical methods}

Electrochemical tests were carried out using a conventional three-electrode cell with a platinum counter electrode, a saturated calomel electrode (SCE) as a reference electrode and a working electrode of stainless steel AISI 304 plate $(2.5 \times 2.5 \mathrm{~cm})$. All polarisation curves were recorded using a potentiostat (Versastat ${ }^{\mathrm{TM}} 4.0$ ). Individual separate anodic and cathodic 
potentiodynamic polarisation measurements were obtained by changing the electrode potential automatically from (cathodic) OCP to $-300 \mathrm{mV}$ vs the OCP and (anodic) OCP to $+300 \mathrm{mV}$ vs OCP, respectively, with a scan rate $0.5 \mathrm{mV} \mathrm{s}^{-1}$. Linear polarisation resistance measurements (LPR) were obtained by changing the potential from -20 to $20 \mathrm{mV}$ versus the measured OCP with a scan rate of $10 \mathrm{mV} \mathrm{min}^{-1}$. Electrochemical impedance spectroscopy (EIS) measurements were carried out using a potentiostat (Versastat ${ }^{\mathrm{TM}} 4.0$ ). Impedance spectra were obtained over a frequency range of $100 \mathrm{kHz}$ to $10 \mathrm{mHz}$ with a $10 \mathrm{mV}$ sine wave as the excitation signal at open circuit potential. SCE and platinum electrodes were used as the reference and counter electrodes respectively.

\subsection{Surface morphology}

The morphology of the 304 stainless steel surface after the corrosion test was also studied by scanning electron microscopy (SEM) using a FEI Quanta 200 operating at $20 \mathrm{kV}$ and different magnifications.

\section{Results and discussion}

\subsection{Open circuit potential}

Open circuit potential measurements were obtained at room temperature for the stainless steel samples in $3 \mathrm{M} \mathrm{HCl}$ without (blank) and with the addition of different concentrations of either $3 \mathrm{~N}-12$ or $3 \mathrm{~N}-18$ gemini surfactants. Figure 2 shows the trend in the OCP with time. The OCP of the blank solution was $-401 \mathrm{mV}_{\mathrm{SCE}}$ after 1 hour, reaching $-355 \mathrm{mV}_{\mathrm{SCE}}$ after $24 \mathrm{~h}$. Adding inhibitors shifted the potential towards more positive values than the values for the blank solution. The stainless steel potential in the blank solutions changed from $-401 \mathrm{mV}_{\mathrm{SCE}}$ to -355 $\mathrm{mV}_{\mathrm{SCE}}$ after 24 hours of immersion. $3 \mathrm{~N}-18$ appeared to be the most efficient as the potential increased from $-348 \mathrm{mV}_{\mathrm{SCE}}$ to $-313 \mathrm{mV}_{\mathrm{SCE}}$ (after 24 hours at $0.01 \mathrm{mM}$ ). While $1 \mathrm{mM}$ was the best concentration of $3 \mathrm{~N}-12$ which shifted OCP from $-352 \mathrm{mV}_{\text {SCE }}$ to $-330 \mathrm{mV}_{\text {SCE. }}$

\subsection{Potentiodynamic polarisation measurements}

Figure 3 and 4 display the potentiodynamic anodic and cathodic polarisation curves of stainless steel in 3M hydrochloric acid in the presence and absence of the selected inhibitors. It is noticeable that both anodic metal dissolution and cathodic hydrogen evolution reactions were reduced by adding the inhibitors. There is a positive shift for the anodic overvoltage and the cathodic overvoltage compared to the blank solution indicating that the synthesised cationic surfactants act as mixed inhibitors. Moreover, the shape of the branches is similar to 
the plots of the blank solution which suggests the corrosion mechanism has not changed and the inhibitors act by an adsorption process onto both anodic and cathodic active sites of the surface [22]. The values of anodic Tafel slope $\left(b_{a}\right)$, cathodic Tafel slope $\left(b_{c}\right)$, corrosion current density $\left(i_{c o r r}\right)$, polarization resistance $\left(R_{p}\right)$, corrosion potential $\left(E_{c o r r}\right)$ and inhibition efficiency (IE\%) were calculated and are listed in Table 1 . Here it is observed that $b_{a}$ values for the inhibited solution are higher when compared to the $b_{a}$ values of the blank solution, while the $b_{c}$ values are compared to the blank solution. These results prove that the surfactants act as mixed inhibitors [22]. It was observed that current corrosion density values decreased after adding inhibitors. For the blank solution the $\mathrm{i}_{\text {corr }}$ value was $2550 \mu \mathrm{A} \mathrm{cm}^{-2}$ (after 24 hours of immersion) whereas in the presence of the inhibitors $i_{\text {corr }}$ was $126 \mu \mathrm{A} \mathrm{cm}^{-2}$ and $203 \mu \mathrm{A} \mathrm{cm}^{-2}$ for $3 \mathrm{~N}-12(1 \mathrm{mM})$ and $3 \mathrm{~N}-18(0.01 \mathrm{mM})$, respectively. $R_{p}$ values were greater for inhibited solutions; being $126 \Omega \mathrm{cm}^{2}$ and $161 \Omega \mathrm{cm}^{2}$ for $3 \mathrm{~N}-12(1 \mathrm{mM})$ and $3 \mathrm{~N}-18(0.01 \mathrm{mM})$ respectively compared to the blank solution value of $13 \Omega \mathrm{cm}^{2}$.

Inhibition efficiency was obtained from the following equation (1) [39]:

$$
\mathrm{IE}=\left(i_{0}-i\right) / i_{0} \times 100 \%
$$

Where $\mathrm{i}$ and $\mathrm{i}_{0}$ are corrosion current density with and without the inhibitor respectively. The values of current corrosion density were calculated using the Stern-Geary equation (2) [21]:

$$
i_{\text {corr }}=\left(b_{a} b_{c} / 2.303\left(b_{a}+b_{c}\right)\right) / R_{p}
$$

From data in Table 1 it was observed that for $3 \mathrm{~N}-12$ IE increased with increasing concentration of the inhibitor and reaching the maximum around CMC value (1.06 $\mathrm{mM} \mathrm{[42])}$ and the behaviour was previously noticed in literature [44]. On increasing the inhibitor concentration above the CMC, IE values for $3 \mathrm{~N}-12$ are quite constant indicating that a stable layer of inhibitors is formed onto the stainless steel surface. Adding additional inhibitor molecules leads to micelles formation which does not change the current corrosion density [45]. This relationship was not observed for $3 \mathrm{~N}-18$. The maximum was reached at $0.01 \mathrm{mM}$ (92\%) whereas CMC is $0.076 \mathrm{mM}$. At concentrations higher than critical micellar concentration value, IE decreases. When CMC is discussed it is important to remember that it is not a single value but it is a range of concentrations which is represented by average. Moreover, gemini surfactants with 18 carbon atoms in a hydrophobic tail are more surface active than compounds with 12 carbon atoms which means they form micelles at lower concentrations and also adsorb onto interfaces at lower concentrations. Furthermore, 
decreasing inhibition efficiency after reaching the CMC value may be attributed to a steric hindrance and repulsion due to the presence of long alkyl chains [7]. This response is similar to the mechanism of biological activity of cationic surfactants, which also relates to the adsorption onto a negatively charged cell membrane (with respect to the negatively charged metal surface). The biological activity of gemini compounds with $\mathrm{C} 18$ in alkyl chains is lower than for C12 due to reflexing of the alkyl chains [46,47].

As mentioned before, the highest inhibition efficiency for 3N-12 $(95 \%)$ was reached at $1 \mathrm{mM}$ whereas for $3 \mathrm{~N}-18(92 \%)$ at $0.01 \mathrm{mM}$. For compound with 18 carbon atoms in the alkyl chains a similar effect is reached at 100-times lower concentration than for compound with 12 carbon atoms. This is associated with micellization process. Elongating the alkyl chain decreases CMC values and that makes compounds active at lower concentrations [48].

\subsection{Electrochemical impedance spectroscopy}

Nyquist impedance diagrams (after 24 hours of immersion) for stainless steel in $3 \mathrm{M} \mathrm{HCl}$ solution without and with various concentrations of the synthesised gemini surfactants are represented in Figure 5. The plots presented exhibit a semicircular shape with a diameter reflecting corrosion resistance (larger diameter, higher corrosion resistance).

The experimental data was fitted to an equivalent circuit model (Figure 6) using the ZView2 ${ }^{\odot}$ programme. The proposed equivalent circuit consists of a solution resistance $\left(R_{s}\right)$, a constant phase element $(C P E-1)$, related to the capacitive behaviour of the inhibitor film formed on the surface of the metal, in parallel with a resistance $\left(R_{\text {in }}\right)$ which is related to defects of the inhibitor film. The second constant phase element $(C P E-2)$ in parallel with a charge transfer resistance $\left(R_{c t}\right)$ is related to the interface between the solution in the defects and the metal surface. Polarization resistance $\left(R_{P}\right)$ was calculated as the sum of $R_{s}, R_{i n}$ and $R_{c t}$ [49].

$C P E$ was used to give a more accurate fit to the experimental results by taking into account the non ideal capacitive behaviour of the system [50]. The $C P E$ of each semi-circle was used to derive the layer capacitance $\left(C_{l}\right)$ using the following equation (3) [51]:

$$
C_{l}=\left(\left(\mathrm{Q}^{*} R\right)^{1 / \mathrm{n}}\right) / R
$$

Where $n$ is the phase shift, (where $n=1$ for ideal capacitive behaviour) [52]. $R$ is the $R_{\text {in }}$ to obtain the capacitance of the solution and the inhibitor layer and $R_{c t}$ to obtain the capacitance of the inhibitor layer and the metal. $C_{l-1}$ is related to inhibitor layer capacitance and as $R$ in 
equation $3, R_{\text {in }}$ wa used. Whereas $C_{l-2}$ is related to double layer capacitance and $\mathrm{R}$ in equation 3 was represented by $R_{c t}$.

Inhibition efficiency (IE) was calculated using charge transfer resistance values according to the following equation (4) [53]:

$$
\mathrm{IE} \%=\left(\left(R_{P}-R_{P}{ }^{0}\right) / R_{P}\right) \mathrm{x} 100
$$

Where $R_{P}$ and $R_{P}{ }^{0}$ are the charge transfer resistance values with and without inhibitors for stainless steel in $3 \mathrm{M} \mathrm{HCl}$, respectively.

Corrosion rate was calculated using following equation (5) [54]:

$$
\text { Corrosion rate }=i_{\text {corr }} * A_{w} * 10 * 3.15 * 10^{7} / n F d
$$

Where $i_{\text {corr }}$ is the current density $\left[\mathrm{A} \mathrm{cm} \mathrm{cm}^{-2}\right], A_{w}-56 \mathrm{~g} \mathrm{~mol}^{-1}$ for iron, $F$ - Faraday's constant $\left(96500 \mathrm{C} \mathrm{mol}^{-1}\right), \mathrm{n}=2, d$ - density of stainless steel $\left(7.93 \mathrm{~g} \mathrm{~cm}^{-3}\right), 3.15^{*} 10^{7}$ - one year in seconds and 10 is a conversion factor to obtain the results in $\mathrm{mm}$ [54]. The current density was calculated from equation (2).

The impedance parameters obtained by fitting the EIS data to the equivalent circuit, the inhibition efficiency (IE) and corrosion rate (CR) are presents in Table 2.

$\mathrm{R}_{\mathrm{p}}$ values increase with increasing inhibitor concentration and reach the highest values around CMC. The rise in the resistance values indicates a reduction of the stainless steel corrosion rate. The double layer capacitance values decrease in the presence of the tested inhibitors from 4890 to 200 and $268 \mu \mathrm{F} / \mathrm{cm}^{2}$ for $3 \mathrm{~N}-12$ and $3 \mathrm{~N}-18$, respectively. In the case of the capacitance of the inhibitor layer it can be observed that it decreases with the increase of the inhibitor concentration in the case of the $3 \mathrm{~N}-12$. This could be indicating an increase in the thickness of the film as more molecules are joining to the film. Regarding the $3 \mathrm{~N}-18$, it can be observed a decrease before the CMC value and how at higher concentrations the capacitance increases again, probably due to the film getting thinner or the interfacial area increased as defects due to the interaction between molecules are formed. The decrease in the capacitance values may also be related to the replacement of the water molecules by the inhibitor molecules according to the following equation (6) [22]:

$$
\operatorname{Inh}_{(\text {sol })}+\mathrm{xH}_{2} \mathrm{O}_{(\mathrm{ads})} \rightarrow \operatorname{Inh}_{(\mathrm{ads})}+\mathrm{xH}_{2} \mathrm{O}_{(\mathrm{sol})}
$$

Where $\operatorname{Inh}_{(\mathrm{sol})} / \operatorname{Inh}_{(\mathrm{ads})}$ are inhibitor molecules in the aqueous phase/adsorbed at the metal surface, $\mathrm{H}_{2} \mathrm{O}_{\text {(ads) }} / \mathrm{H}_{2} \mathrm{O}_{\text {(sol) }}$ are water molecules adsorbed at the metal /in the aqueous phase and $\mathrm{x}$ is the molar ratio, the number of water molecules replaced by one inhibitor molecule. 
Decrease $C_{l}$ values result from a decrease of the local dielectric constant and/or increase in the electrical double layer thickness, suggesting the inhibitors act by adsorption at the metal/solution interface $[55,56]$ In the case of $3 \mathrm{~N}-18$, at concentration above CMC value $(\mathrm{C}=1 \mathrm{mM}) C_{l}$ values increased due to thinning of the protective film.

Figure 7 presents the evolution of the corrosion resistance with immersion time for the tested gemini surfactants.

Initially, after $1 \mathrm{~h}$ it is suggested that there is not full coverage of the surface by the $3 \mathrm{~N}-12$ molecules, the highest concentration of the inhibitor is providing the highest degree of protection, due to the quicker diffusion to the surface and the highest value of $R_{p}$. With continued immersion (up to 24 hours), the decrease of charge transfer resistance slows down and becomes more constant for both, $1 \mathrm{mM}$ and $2 \mathrm{mM}$ solutions than for that of the other concentrations. However, for $3 \mathrm{~N}-18$, the concentration higher than $\mathrm{CMC}$ values is reducing the protectiveness of the metal from the beginning of the immersion (the highest charge transfer resistance was observed for $0.01 \mathrm{mM}$ solution). Therefore, in the case of the $3 \mathrm{~N}-18$ inhibitor, the effect of the steric hindrance and repulsion due to the presence of long alkyl chains is observed from the beginning of the immersion.

The inhibition efficiency of the gemini surfactants obtained from the EIS measurements is in good agreement with the values obtained from the polarisation measurements.

\subsection{Adsorption isotherm}

The first step of corrosion inhibition is the adsorption of the inhibitor molecules at the metal/solution interface [22]. On this basis the data (IE) obtained from the EIS measurements have been converted to surface coverage and then fitted to different theoretical adsorption isotherms [57]. The surface coverage $(\theta)$ was calculated from equation (7) [58]:

$$
\theta=\mathrm{IE} \% / 100
$$

Analysis of the results suggests the Langmuir adsorption isotherm equation (8) provides the best fitting ( $\mathrm{R}^{2}$ close to 1 ) for the results obtained with the inhibitors $[57,59]$.

$$
\mathrm{C} / \theta=\left(1 / K_{a d s}\right)+\mathrm{C}
$$

Where $\mathrm{C}$ is the inhibitor concentration $\left[\mathrm{mol} / \mathrm{dm}^{3}\right]$ and $K_{a d s}$ is the adsorptive equilibrium constant.

A plot of $\mathrm{C} / \theta$ vs $\mathrm{C}$ is presented in Figure 8. A linear regression was used and intercepts were determined by extrapolation. Each intercept was equal to the reciprocal of the adsorptive 
equilibrium constant $\left(K_{a d s}\right)$ [22] and this parameter was used to determine the Gibbs free energy $\left(\Delta G_{a d s}\right)$ based upon equation (9) [29,30]:

$$
\Delta G_{a d s}=-R T \ln \left(55.5 K_{a d s}\right)
$$

Where $R$ is the gas constant $\left(8.314 \mathrm{~J} \mathrm{~mol}^{-1} \mathrm{~K}^{-1}\right), T$ is temperature $(\mathrm{K})$ and the value 55.5 is the molar concentration of water. The values of $K_{a d s}$ and $\Delta G_{a d s}$ are reported in Table 3.

The calculated $\Delta \mathrm{G}_{\mathrm{ads}}$ values are negative indicating the adsorption process is spontaneous and the range of values, between -34.49 and $-48.17 \mathrm{~kJ} / \mathrm{mol}$, reveal that the process involves both physisorption and chemisorption for $3 \mathrm{~N}-12$ and chemisorption for $3 \mathrm{~N}-18 . \Delta \mathrm{G}_{\mathrm{ads}}>-20 \mathrm{~kJ} / \mathrm{mol}$ indicates pure physisorption, the electrostatic interaction between charged inhibitor molecules and charged metal surface whereas $\Delta \mathrm{G}_{\mathrm{ads}}<-40 \mathrm{~kJ} / \mathrm{mol}$ involves chemisorption [45].

It can be observed that the fitting in the case of the long chain inhibitor, $3 \mathrm{~N}-18$, is not showing perfect linearity to the Langmuir isotherm as a consequence of interactions between molecules, such as steric hindrance and the repulsion of long alkyl chains [60] which was also the reason of taking out the last point in the graph $(0.1 \mathrm{mM})$ from the fitting. Langmuir isotherms are based on certain assumptions such as monolayer adsorption and identical molecules without any lateral interaction. However, the Langmuir isotherm is the one with the best fitting to the experimental data and, as far as the system is following a Langmuir trend, helps to provide some insights in the way the molecules are adsorbed on the metal surface.

\subsection{Surface morphology}

To confirm the inhibition effect of the gemini surfactants, recorded from the electrochemical tests, on AISI 304 stainless steel, SEM micrographs were obtained from surfaces exposed to 3 $\mathrm{M} \mathrm{HCl}$ and surfaces exposed to $3 \mathrm{M} \mathrm{HCl}$ in the presence of $3 \mathrm{~N}-12(1 \mathrm{mM})$ and $3 \mathrm{~N}-18(0.01$ $\mathrm{mM}$ ) (Figure 9a-d). Here it can be seen that the surface of the metal prior to immersion in the $3 \mathrm{M} \mathrm{HCl}$ solution is free from any detectable defects (Figure 9a). Figure 9b represents the stainless steel in uninhibited solution of $3 \mathrm{M} \mathrm{HCl}$, which shows a heavily corroded surface with the presence of pits. The stainless steel surface was smoother, showing less damage, in the presence of both inhibitors (Figure 9c and d), indicating that tested gemini surfactants reduce the corrosion rate of stainless steel in $3 \mathrm{M} \mathrm{HCl}$. This is considered to be due to the formation of a protective layer on the metal surface, SEM observation of the sample surfaces after exposure to the different solutions with inhibitors, shows limited attack of the surface and is in agreement with the electrochemical results. 
The roughness $\left(R_{a}\right)$ of the stainless steel surface was determined (Table 4) from the VK Analyzer based on micrographs taken using confocal laser scanning microscopy. The inhibited steel surface is smoother than the uninhibited surface indicating that the presence of a protective layer of adsorbed molecules reduces corrosion attack and in turn, the rate of corrosion of stainless steel in $3 \mathrm{M} \mathrm{HCl}$.

\section{Conclusion}

The studied gemini surfactants with 3-azamethyl pentamethylene spacer are good inhibitors, exhibiting efficiencies above $90 \%$, when added to the $3 \mathrm{M} \mathrm{HCl}$ at a concentration level around the CMC. Elongating the alkyl chain from $\mathrm{C} 12$ to $\mathrm{C} 18$ increases the inhibition efficiency for lower concentrations. $3 \mathrm{~N}-18$ reached a similar level of inhibition at surfactant concentrations 100-times lower than $3 \mathrm{~N}-12$. The Langmuir isotherm was used to model the adsorption of the inhibitors and the parameters indicated that both chemisorption and physisorption took place. In the presence of the inhibitors, the open circuit potential of the stainless steel shifts towards more positive values, than that of the blank sample, suggesting the formation of protective layer on the stainless steel surface. The studied surfactants act as mixed-type inhibitors by affecting both cathodic and anodic sites without changing the corrosion mechanism, but reducing the active surface.

\section{Acknowledgement}

This work has been supported by the National Centre for Research and Development (Poland; TANGO1/266340/NCBR/2015).

The authors would also like to thank the School of Materials, University of Manchester for providing research facilities.

\section{References}

[1] S.K. Verma, K.K. Ghosh, Micellar and Surface Properties of Some Monomeric Surfactants and a Gemini Cationic Surfactant, J. Surfactants Deterg. 14 (2011) 347-352. doi:10.1007/s11743-010-1237-0.

[2] B. Brycki, M. Waligórska, A. Szulc, The biodegradation of monomeric and dimeric alkylammonium surfactants, J. Hazard. Mater. 280 (2014) 797-815. doi:10.1016/j.jhazmat.2014.08.021.

[3] D. Shukla, V.K. Tyagi, Cationic gemini surfactants: a review, J. Oleo Sci. 55 (2006) 381-390. doi:10.56500/jos.55.381.

[4] T. Yoshimura, N. Chiba, K. Matsuoka, Supra-long chain surfactants with double or triple quaternary ammonium headgroups, J. Colloid Interface Sci. 374 (2012) 157-163. doi:10.1016/j.jcis.2012.01.033. 
[5] A. Koziróg, B. Brycki, Monomeric and gemini surfactants as antimicrobial agents influence on environmental and reference strains, Acta Biochim. Pol. 62 (2015) 879883. doi:10.18388/abp.2015_1150.

[6] N.A. Negm, M.F. Zaki, M.A.I. Salem, Antibacterial and Antifungal Activities-Surface Active Properties Relation of Novel Dischiff Base Cationic Gemini Amphiphiles Bearing Homogeneous Hydrophobes, J. Dispers. Sci. Technol. 31 (2010) 1390-1395. doi:10.1080/01932690903269784.

[7] S.D. Wettig, C. Wang, R.E. Verrall, M. Foldvari, Thermodynamic and aggregation properties of aza- and imino-substituted gemini surfactants designed for gene delivery, Phys Chem Chem Phys. 9 (2007) 871-877. doi:10.1039/B613269C.

[8] M.T. Garcia, O. Kaczerewska, I. Ribosa, B. Brycki, P. Materna, M. Drgas, Biodegradability and aquatic toxicity of quaternary ammonium-based gemini surfactants: Effect of the spacer on their ecological properties, Chemosphere. 154 (2016) 155-160. doi:10.1016/j.chemosphere.2016.03.109.

[9] R. Zana, J. Xia, Gemini surfactants: synthesis, interfacial and solution-phase behavior, and applications, Marcel Dekker, New York, 2004. http://www.chemlibnetbase.com/ejournals/books/book_km.asp?id=2399 (accessed October 5, 2016).

[10] K. Gharanjig, M. Sadeghi-Kiakhani, A.R. Tehrani-Bagha, A. Khosravi, F.M. Menger, Solubility of Two Disperse Dyes Derived from N-Alkyl and N-Carboxylic Acid Naphthalimides in the Presence of Gemini Cationic Surfactants, J. Surfactants Deterg. 14 (2011) 381-389. doi:10.1007/s11743-011-1253-8.

[11] A. Tehrani-Bagha, K. Holmberg, Solubilization of Hydrophobic Dyes in Surfactant Solutions, Materials. 6 (2013) 580-608. doi:10.3390/ma6020580.

[12] A.R. Tehrani-Bagha, R.G. Singh, K. Holmberg, Solubilization of two organic dyes by cationic ester-containing gemini surfactants, J. Colloid Interface Sci. 376 (2012) 112118. doi:10.1016/j.jcis.2012.02.016.

[13] L.L. Schramm, E.N. Stasiuk, D.G. Marangoni, 2 Surfactants and their applications, Annu Rep Prog Chem Sect C Phys Chem. 99 (2003) 3-48. doi:10.1039/B208499F.

[14] N. Kumar, R. Tyagi, Industrial Applications of Dimeric Surfactants: A Review, J. Dispers. Sci. Technol. 35 (2014) 205-214. doi:10.1080/01932691.2013.780243.

[15] M.A. Al-Dulaymi, J.M. Chitanda, W. Mohammed-Saeid, H.Y. Araghi, R.E. Verrall, P. Grochulski, I. Badea, Di-Peptide-Modified Gemini Surfactants as Gene Delivery Vectors: Exploring the Role of the Alkyl Tail in Their Physicochemical Behavior and Biological Activity, AAPS J. 18 (2016) 1168-1181. doi:10.1208/s12248-016-9906-1.

[16] E. Fisicaro, C. Compari, F. Bacciottini, L. Contardi, E. Pongiluppi, N. Barbero, G. Viscardi, P. Quagliotto, G. Donofrio, M.P. Krafft, Nonviral gene-delivery by highly fluorinated gemini bispyridinium surfactant-based DNA nanoparticles, J. Colloid Interface Sci. 487 (2017) 182-191. doi:10.1016/j.jcis.2016.10.032.

[17] L.Y. Zakharova, D.R. Gabdrakhmanov, A.R. Ibragimova, E.A. Vasilieva, I.R. Nizameev, M.K. Kadirov, E.A. Ermakova, N.E. Gogoleva, D.A. Faizullin, A.G. Pokrovsky, V.A. Korobeynikov, S.V. Cheresiz, Y.F. Zuev, Structural, biocomplexation and gene delivery properties of hydroxyethylated gemini surfactants with varied spacer length, Colloids Surf. B Biointerfaces. $140 \quad$ (2016) 269-277. doi:10.1016/j.colsurfb.2015.12.045.

[18] S.M. Tawfik, Ionic liquids based gemini cationic surfactants as corrosion inhibitors for carbon steel in hydrochloric acid solution, J. Mol. Liq. 216 (2016) 624-635. doi:10.1016/j.molliq.2016.01.066. 
[19] F.A. Ansari, M.A. Quraishi, Inhibitive Effect of Some Gemini Surfactants as Corrosion Inhibitors for Mild Steel in Acetic Acid Media, Arab. J. Sci. Eng. 36 (2011) 11-20. doi:10.1007/s13369-010-0008-6.

[20] M. Mobin, S. Masroor, Alkanediyl- $\alpha, \omega$-bis (dimethyl cetylammonium bromide) gemini surfactants as novel corrosion inhibitors for mild steel in formic acid, Mater. Res. 15 (2012) 837-847. doi:10.1590/S1516-14392012005000112.

[21] N.A. Negm, A.M.A. Sabagh, M.A. Migahed, H.M.A. Bary, H.M.E. Din, Effectiveness of some diquaternary ammonium surfactants as corrosion inhibitors for carbon steel in 0.5M HCl solution, Corros. Sci. 52 (2010) 2122-2132. doi:10.1016/j.corsci.2010.02.044.

[22] M.A. Hegazy, S.S. Abd El-Rehim, E.A. Badr, W.M. Kamel, A.H. Youssif, Mono-, Diand Tetra-Cationic Surfactants as Carbon Steel Corrosion Inhibitors, J. Surfactants Deterg. 18 (2015) 1033-1042. doi:10.1007/s11743-015-1727-1.

[23] M.A. Migahed, M.M. Shaban, A.A. Fadda, T.A. Ali, N.A. Negm, Synthesis of some quaternary ammonium gemini surfactants and evaluation of their performance as corrosion inhibitors for carbon steel in oil well formation water containing sulfide ions, RSC Adv. 5 (2015) 104480-104492. doi:10.1039/C5RA15112K.

[24] M.A. Hegazy, M. Abdallah, M.K. Awad, M. Rezk, Three novel di-quaternary ammonium salts as corrosion inhibitors for API X65 steel pipeline in acidic solution. Part I: Experimental results, Corros. Sci. 81 (2014) 54-64. doi:10.1016/j.corsci.2013.12.010.

[25] C.G. Darive, A.F. Galio, Corrosion Inhibitors - Principles, Mechanisms and Applications, in: M. Aliofkhazraei (Ed.), Dev. Corros. Prot., InTech, 2014. http://www.intechopen.com/books/developments-in-corrosion-protection/corrosioninhibitors-principles-mechanisms-and-applications (accessed October 5, 2016).

[26] S.M. Tawfik, Corrosion inhibition efficiency and adsorption behavior of N,N-dimethyl4-(((1-methyl-2-phenyl-2,3-dihydro-1H-pyrazol-4-yl)imino)methyl)-Nalkylbenzenaminium bromide surfactant at carbon steel/hydrochloric acid interface, J. Mol. Liq. 207 (2015) 185-194. doi:10.1016/j.molliq.2015.03.036.

[27] M.A. Hegazy, E.M.S. Azzam, N.G. Kandil, A.M. Badawi, R.M. Sami, Corrosion Inhibition of Carbon Steel Pipelines by Some New Amphoteric and Di-cationic Surfactants in Acidic Solution by Chemical and Electrochemical Methods, J. Surfactants Deterg. 19 (2016) 861-871. doi:10.1007/s11743-016-1824-9.

[28] M.A. Hegazy, A.Y. El-Etre, M. El-Shafaie, K.M. Berry, Novel cationic surfactants for corrosion inhibition of carbon steel pipelines in oil and gas wells applications, J. Mol. Liq. 214 (2016) 347-356. doi:10.1016/j.molliq.2015.11.047.

[29] M. Mobin, R. Aslam, S. Zehra, M. Ahmad, Bio-/Environment-Friendly Cationic Gemini Surfactant as Novel Corrosion Inhibitor for Mild Steel in $1 \mathrm{M} \mathrm{HCl}$ Solution, J. Surfactants Deterg. 20 (2017) 57-74. doi:10.1007/s11743-016-1904-X.

[30] M.S. Shihab, A.F. Mahmood, Experimental and Theoretical Study of Some Npyridinium Salt Derivatives as Corrosion Inhibitors for Mild-steel in 1 M H2SO4:, Port. Electrochimica Acta. 35 (2017) 39-51. doi:10.4152/pea.201701039.

[31] I. Aiad, M.M. El-Sukkary, E.A. Soliman, M.Y. El-Awady, S.M. Shaban, Characterization, surface properties and biological activity of new prepared cationic surfactants, J. Ind. Eng. Chem. 20 (2014) 1633-1640. doi:10.1016/j.jiec.2013.08.010.

[32] B. Li, Q. Zhang, Y. Xia, Z. Gao, Surface properties and aggregation behavior of cationic gemini surfactants with dipropylammonium head-groups, Colloids Surf. Physicochem. Eng. Asp. 470 (2015) 211-217. doi:10.1016/j.colsurfa.2015.02.005.

[33] M. Hajy Alimohammadi, S. Javadian, H. Gharibi, A. reza Tehrani-Bagha, M.R. Alavijeh, K. Kakaei, Aggregation behavior and intermicellar interactions of cationic 
Gemini surfactants: Effects of alkyl chain, spacer lengths and temperature, J. Chem. Thermodyn. 44 (2012) 107-115. doi:10.1016/j.jct.2011.08.007.

[34] M.C. Murguía, L.M. Machuca, M.C. Lurá, M.I. Cabrera, R.J. Grau, Synthesis and Properties of Novel Antifungal Gemini Compounds Derived from N-Acetyl Diethanolamines, J. Surfactants Deterg. 11 (2008) 223-230. doi:10.1007/s11743-0081076-4.

[35] Q. Zhang, Z. Gao, F. Xu, S. Tai, Effect of hydrocarbon structure of the headgroup on the thermodynamic properties of micellization of cationic gemini surfactants: An electrical conductivity study, J. Colloid Interface Sci. 371 (2012) 73-81. doi:10.1016/j.jcis.2011.12.076.

[36] X. Wang, J. Wang, Y. Wang, H. Yan, P. Li, R.K. Thomas, Effect of the Nature of the Spacer on the Aggregation Properties of Gemini Surfactants in an Aqueous Solution, Langmuir. 20 (2004) 53-56. doi:10.1021/la0351008.

[37] V. de F.C. Lins, G.A. dos S. Gonçalves, T.P. Leão, R.B. Soares, C.G.F. Costa, A.K. do N. Viana, Corrosion resistance of AISI 304 and 444 stainless steel pipes in sanitizing solutions of clean-in-place process, Mater. Res. 19 (2016) 333-338. doi:10.1590/19805373-MR-2015-0298.

[38] A.-R. Grayeli-Korpi, H. Savaloni, M. Habibi, Corrosion inhibition of stainless steel type AISI 304 by Mn coating and subsequent annealing with flow of nitrogen at different temperatures, Appl. Surf. Sci. 276 (2013) 269-275. doi:10.1016/j.apsusc.2013.03.081.

[39] M. Abdallah, H.M. Eltass, M.A. Hegazy, H. Ahmed, Adsorption and inhibition effect of novel cationic surfactant for pipelines carbon steel in acidic solution, Prot. Met. Phys. Chem. Surf. 52 (2016) 721-730. doi:10.1134/S207020511604002X.

[40] M.A. Migahed, S.M. Rashwan, M.M. Kamel, R.E. Habib, Synthesis, characterization of polyaspartic acid-glycine adduct and evaluation of their performance as scale and corrosion inhibitor in desalination water plants, J. Mol. Liq. 224 (2016) 849-858. doi:10.1016/j.molliq.2016.10.091.

[41] F.-Y. Ma, Corrosive effects of chlorides on metals, INTECH Open Access Publisher, 2012. http://cdn.intechopen.com/pdfs/33625/intechcorrosive_effects_of_chlorides_on_metals.pdf (accessed February 9, 2017).

[42] M. Teresa Garcia, O. Kaczerewska, I. Ribosa, B. Brycki, P. Materna, M. Drgas, Hydrophilicity and flexibility of the spacer as critical parameters on the aggregation behavior of long alkyl chain cationic gemini surfactants in aqueous solution, J. Mol. Liq. (2017). doi:10.1016/j.molliq.2017.01.053.

[43] O. Kaczerewska, Corrosion inhibition efficiency of functionalized dimeric tetraalkylammonium salts, PhD dissertation, Adam Mickiewicz University in Poznań, 2017.

[44] M.A. Malik, M.A. Hashim, F. Nabi, S.A. Al-Thabaiti, Z. Khan, Anti-corrosion ability of surfactants: a review, Int J Electrochem Sci. 6 (2011) 1927-1948.

[45] S.M. Tawfik, A.A. Abd-Elaal, I. Aiad, Three gemini cationic surfactants as biodegradable corrosion inhibitors for carbon steel in $\mathrm{HCl}$ solution, Res. Chem. Intermed. 42 (2016) 1101-1123. doi:10.1007/s11164-015-2076-4.

[46] J. Hoque, P. Akkapeddi, V. Yarlagadda, D.S.S.M. Uppu, P. Kumar, J. Haldar, Cleavable Cationic Antibacterial Amphiphiles: Synthesis, Mechanism of Action, and Cytotoxicities, Langmuir. 28 (2012) 12225-12234. doi:10.1021/la302303d.

[47] J.E. LaDow, D.C. Warnock, K.M. Hamill, K.L. Simmons, R.W. Davis, C.R. Schwantes, D.C. Flaherty, J.A.L. Willcox, K. Wilson-Henjum, K.L. Caran, K.P.C. Minbiole, K. Seifert, Bicephalic amphiphile architecture affects antibacterial activity, Eur. J. Med. Chem. 46 (2011) 4219-4226. doi:10.1016/j.ejmech.2011.06.026. 
[48] R. Zana, Alkanediyl- $\alpha, \omega$-bis(dimethylalkylammonium bromide) Surfactants, J. Colloid Interface Sci. 246 (2002) 182-190. doi:10.1006/jcis.2001.7921.

[49] S. Varvara, M. Popa, G. Rustoiu, R. Bostan, L. Mureşan, Evaluation of some amino acids as bronze corrosion inhibitors in aqueous solution, Stud. Univ. Babes-Bolyai Chem. 2 (2009) 73-85.

[50] M.A. Hegazy, Novel cationic surfactant based on triazole as a corrosion inhibitor for carbon steel in phosphoric acid produced by dihydrate wet process, J. Mol. Liq. 208 (2015) 227-236. doi:10.1016/j.molliq.2015.04.042.

[51] R. Leiva-García, J.C.S. Fernandes, M.J. Muñoz-Portero, J. García-Antón, Study of the sensitisation process of a duplex stainless steel (UNS 1.4462) by means of confocal microscopy and localised electrochemical techniques, Corros. Sci. 94 (2015) 327-341. doi:10.1016/j.corsci.2015.02.016.

[52] M.A. Hegazy, S.M. Rashwan, M.M. Kamel, M.S. El Kotb, Synthesis, surface properties and inhibition behavior of novel cationic gemini surfactant for corrosion of carbon steel tubes in acidic solution, J. Mol. Liq. 211 (2015) 126-134. doi:10.1016/j.molliq.2015.06.051.

[53] A. Labena, M.A. Hegazy, H. Horn, E. Müller, Cationic Gemini Surfactant as a Corrosion Inhibitor and a Biocide for High Salinity Sulfidogenic Bacteria Originating from an Oil-Field Water Tank, J. Surfactants Deterg. 17 (2014) 419-431. doi:10.1007/s11743-013-1551-4.

[54] M. Dehdab, Z. Yavari, M. Darijani, A. Bargahi, The inhibition of carbon-steel corrosion in seawater by streptomycin and tetracycline antibiotics: An experimental and theoretical study, Desalination. 400 (2016) 7-17. doi:10.1016/j.desal.2016.09.007.

[55] J. Aljourani, K. Raeissi, M.A. Golozar, Benzimidazole and its derivatives as corrosion inhibitors for mild steel in 1M HCl solution, Corros. Sci. 51 (2009) 1836-1843. doi:10.1016/j.corsci.2009.05.011.

[56] D.K. Yadav, B. Maiti, M.A. Quraishi, Electrochemical and quantum chemical studies of 3,4-dihydropyrimidin-2 $(1 \mathrm{H})$-ones as corrosion inhibitors for mild steel in hydrochloric acid solution, Corros. Sci. 52 (2010) 3586-3598. doi:10.1016/j.corsci.2010.06.030.

[57] J.T. Nwabanne, V.N. Okafor, others, Adsorption and Thermodynamics Study of the Inhibition of Corrosion of Mild Steel In H 2 SO 4 Medium Using Vernonia Amygdalina, J. Miner. Mater. Charact. Eng. 11 (2012) 885.

[58] S.S.A. El Rehim, H.H. Hassan, M.A. Amin, The corrosion inhibition study of sodium dodecyl benzene sulphonate to aluminium and its alloys in $1.0 \mathrm{M} \mathrm{HCl}$ solution, Mater. Chem. Phys. 78 (2003) 337-348.

[59] R. Chen, L. Guo, S. Xu, Experimental and Theoretical Investigation of 1hydroxybenzotriazole as a Corrosion Inhibitor for Mild Steel in Sulfuric Acid Medium, Int J Electrochem Sci. 9 (2014) 6880-6895.

[60] K.Y. Foo, B.H. Hameed, Insights into the modeling of adsorption isotherm systems, Chem. Eng. J. 156 (2010) 2-10. doi:10.1016/j.cej.2009.09.013. 


\section{FIGURES AND TABLES}

Figure 1. Structure of the N-substituted gemini surfactants.

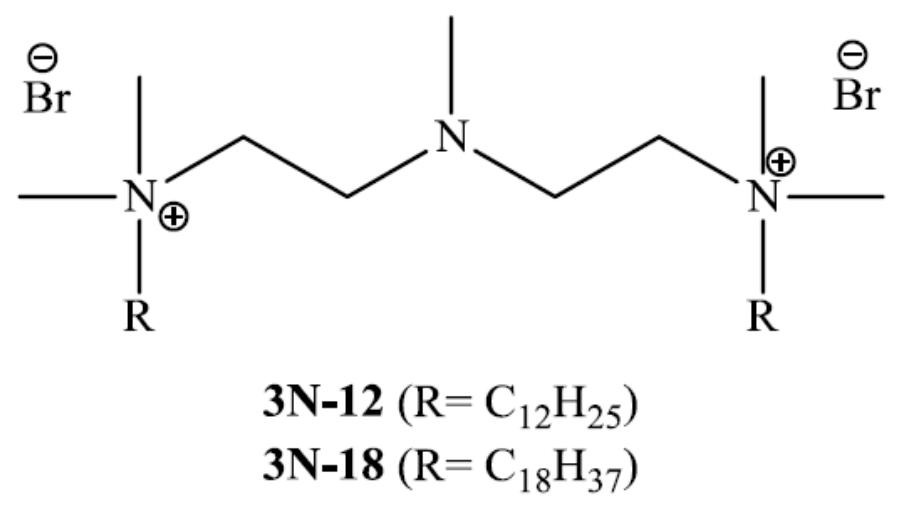


Figure 2. Open circuit potential-time curves for stainless steel electrode immersed in $3 \mathrm{M} \mathrm{HCl}$ in the absence and presence of synthesised cationic surfactants.

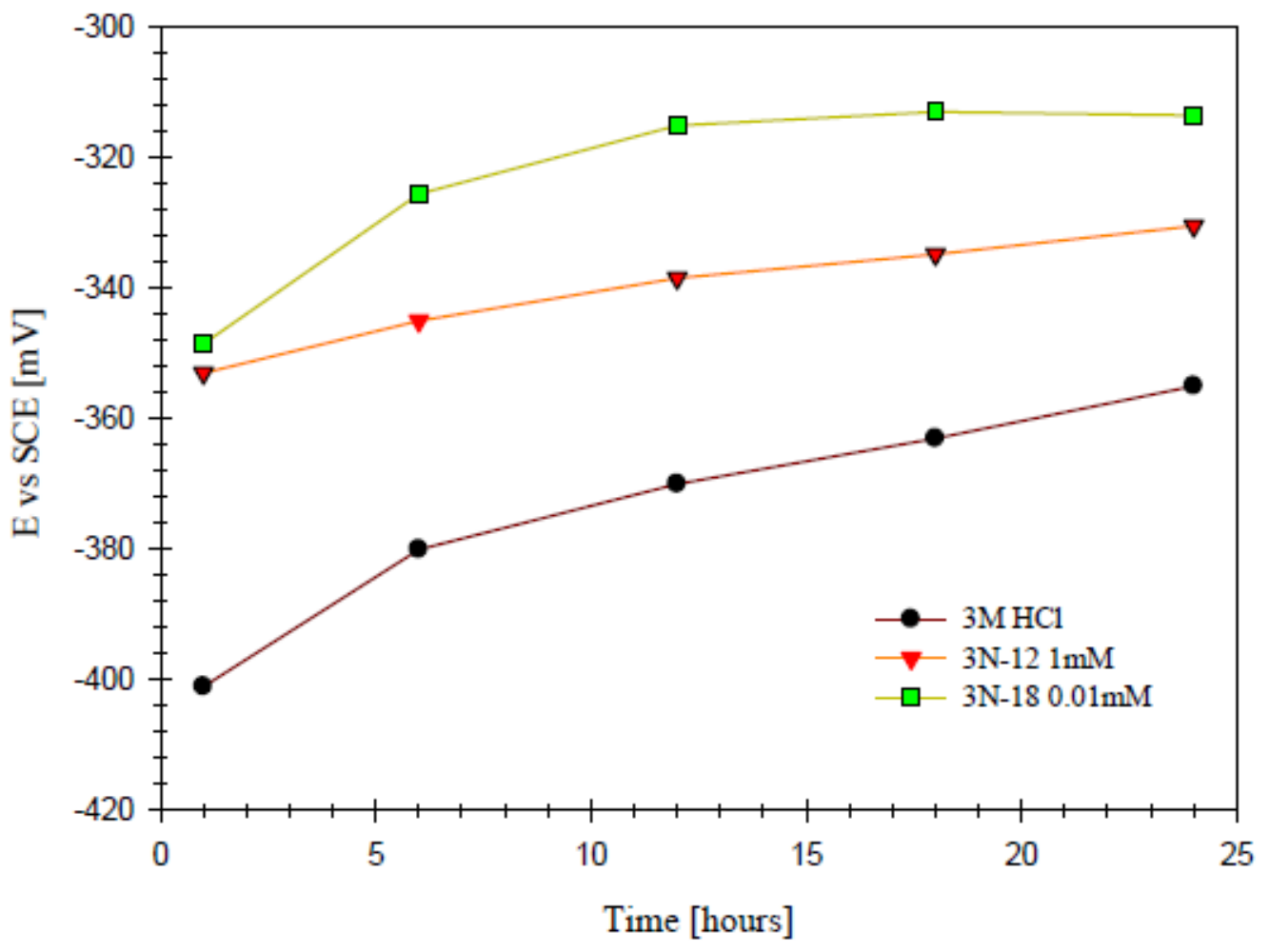


Figure 3.Tafel plots for stainless steel in $3 \mathrm{M} \mathrm{HCl}$ and $3 \mathrm{M} \mathrm{HCl}$ with different concentrations of $3 \mathrm{~N}-12$.

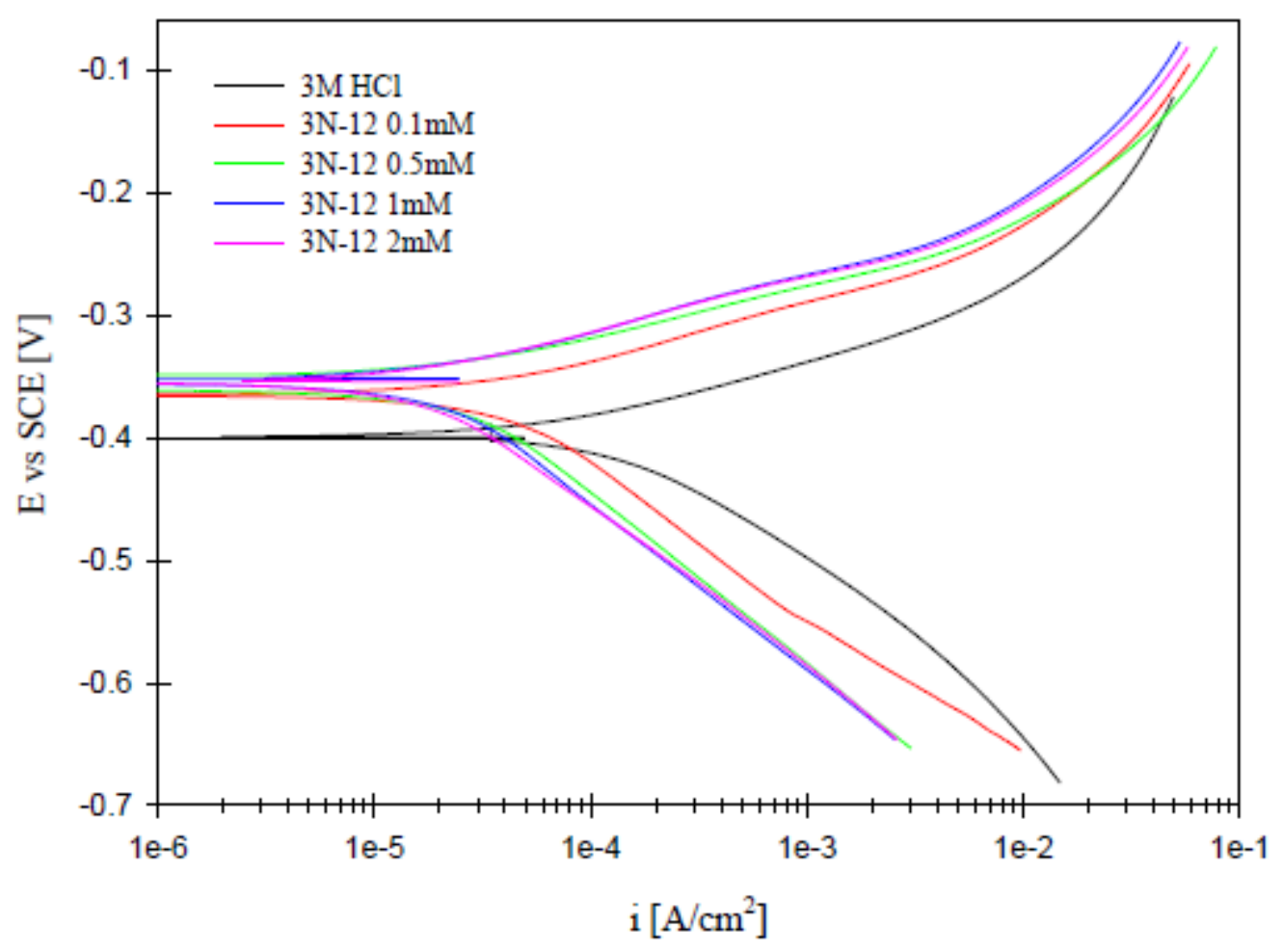


Figure 4. Tafel plots for stainless steel in $3 \mathrm{M} \mathrm{HCl}$ and $3 \mathrm{M} \mathrm{HCl}$ with different concentrations of $3 \mathrm{~N}-18$.

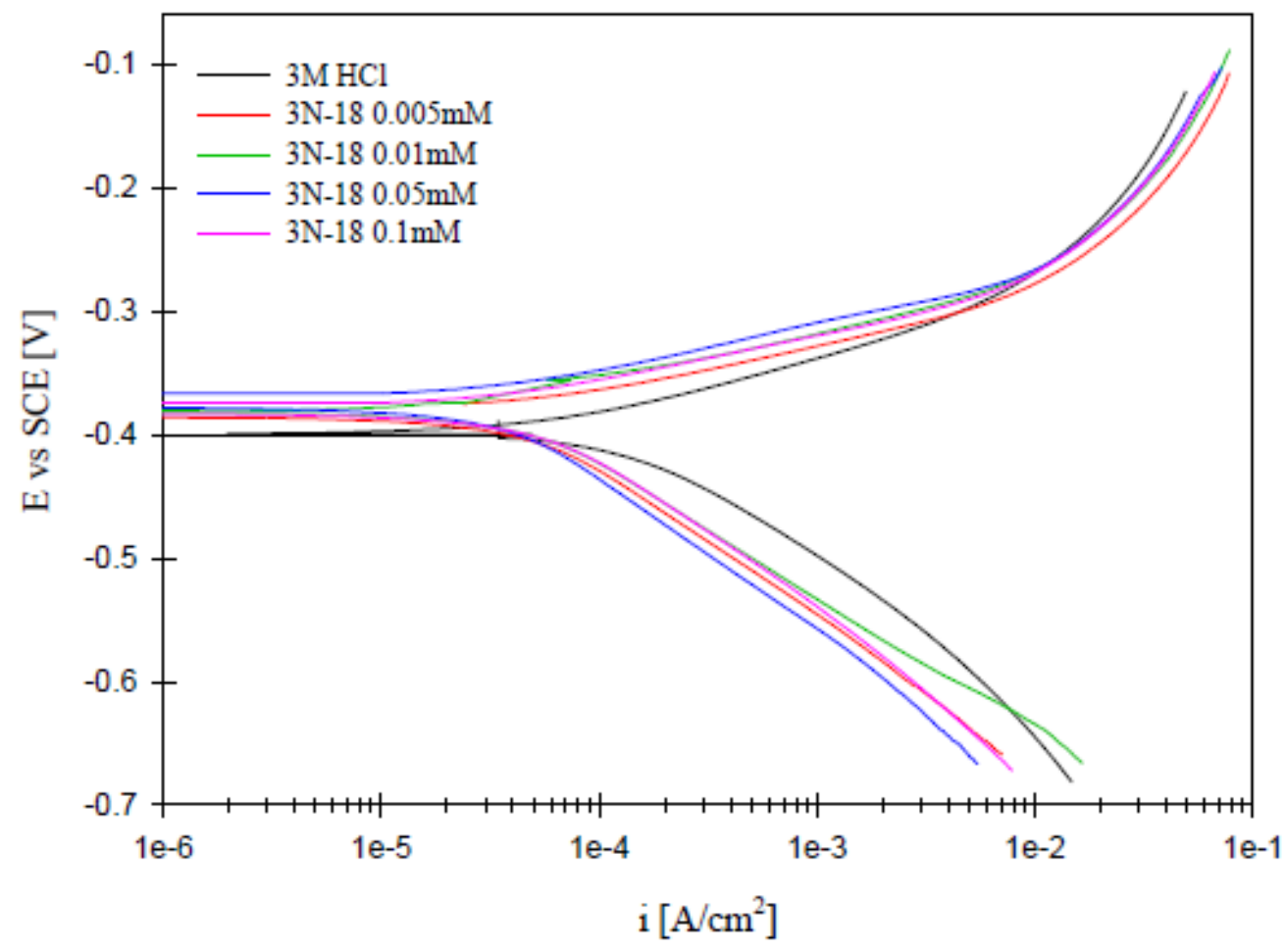


Figure 5. Nyquist plots for stainless steel in $3 \mathrm{M} \mathrm{HCl}$ in the presence and absence of selected inhibitors (at their most effective concentrations).

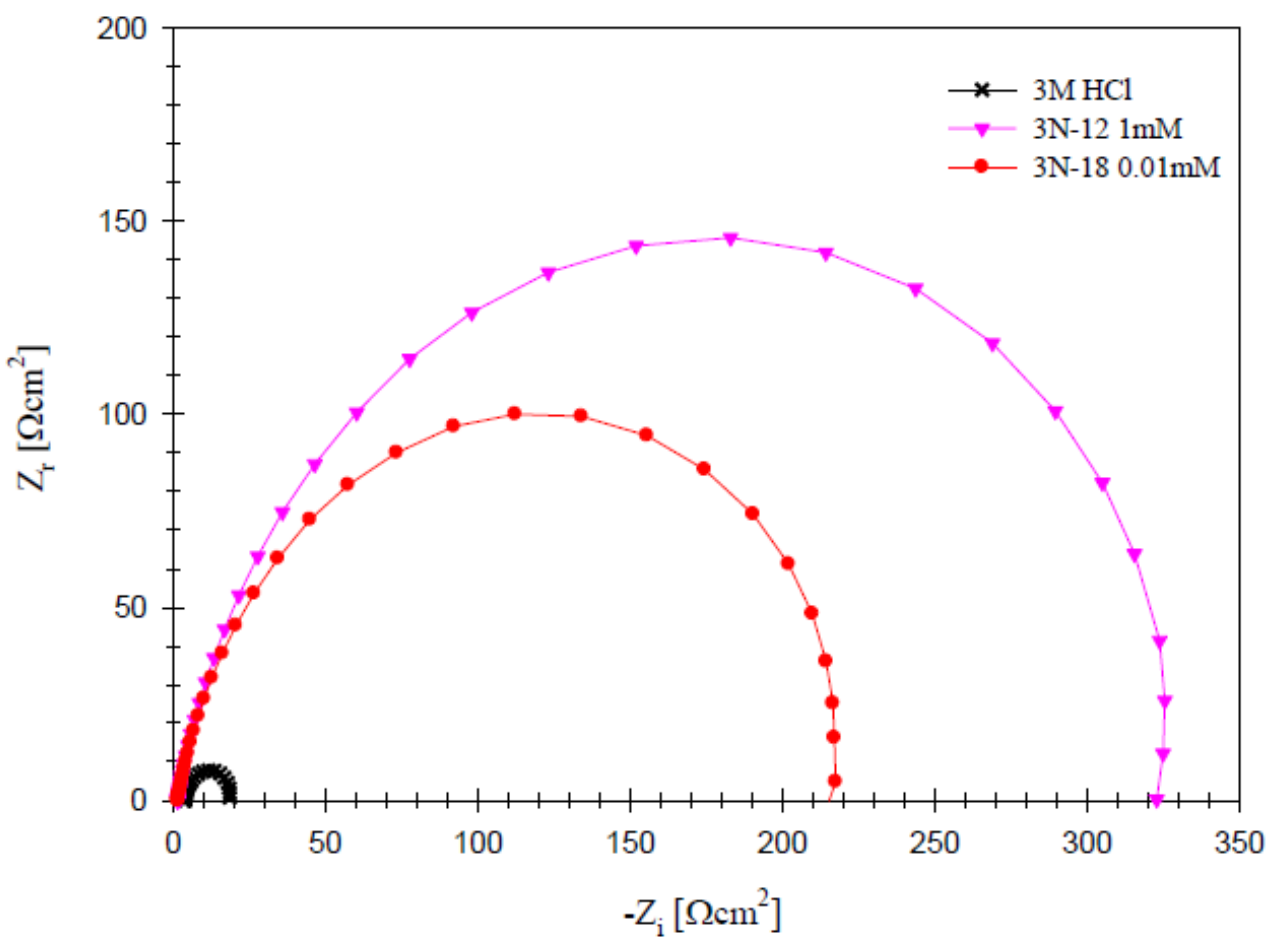


Figure 6. The equivalent circuit for the studied system.

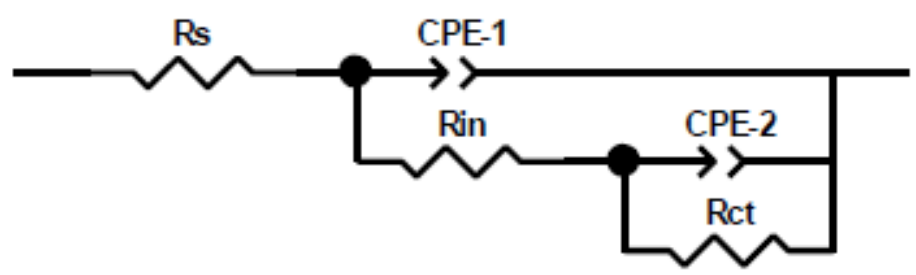


Figure 7. The evolution of charge transfer resistance with the time plots for tested gemini surfactants.

$3 \mathrm{~N}-12$

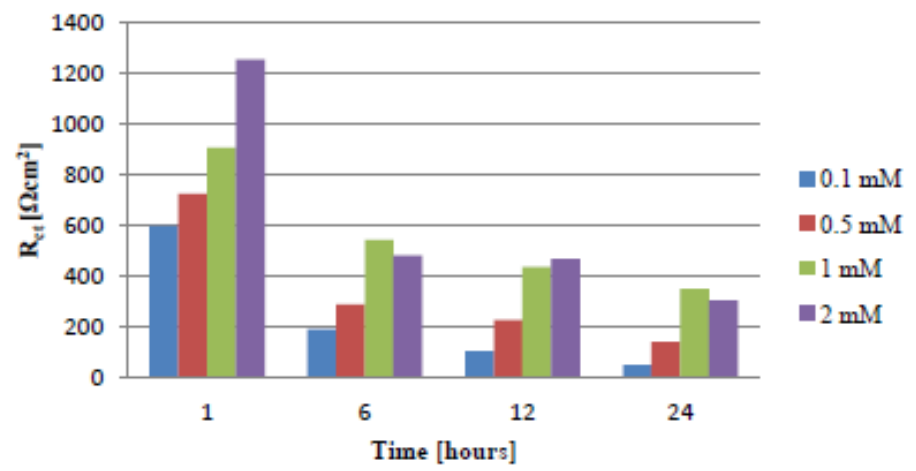

3N-18

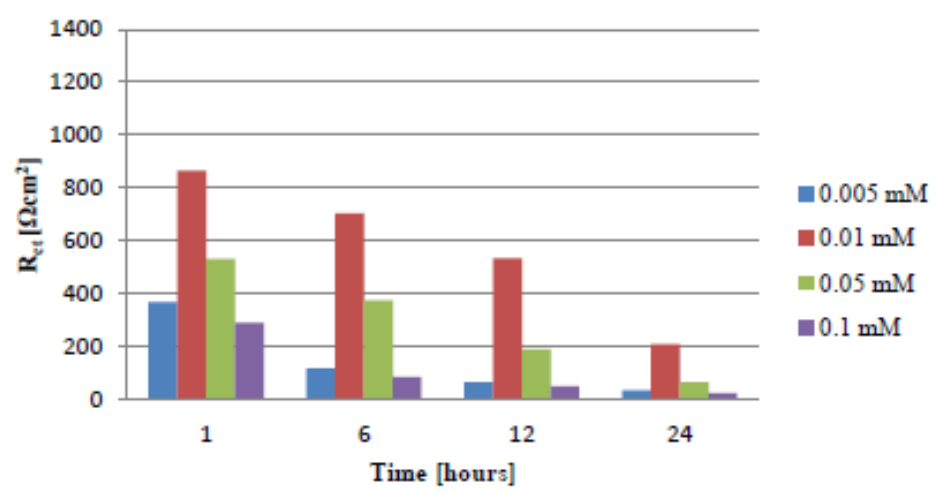


Figure 8. Langmuir isotherm adsorption model of $3 \mathrm{~N}-12$ and $3 \mathrm{~N}-18$ for stainless steel i $3 \mathrm{M}$ $\mathrm{HCl}$.
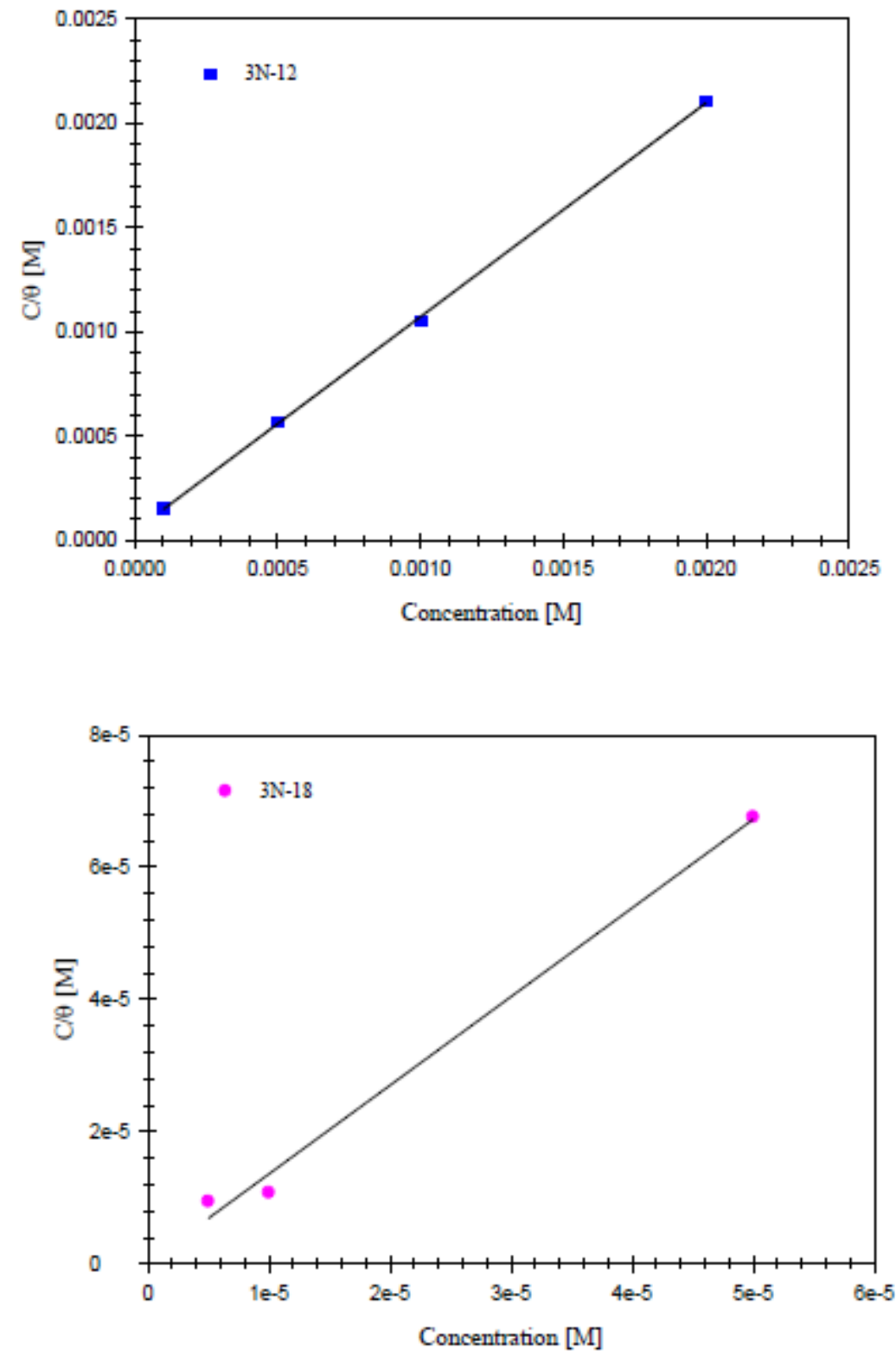
Figure 9. SEM images of stainless steel surface: a) before immersion; b) after immersion in $3 \mathrm{M} \mathrm{HCl}$; c) after immersion in $3 \mathrm{M} \mathrm{HCl}$ with $3 \mathrm{~N}-12(1 \mathrm{mM})$; d) after immersion in $3 \mathrm{M} \mathrm{HCl}$ with $3 \mathrm{~N}-18(0.01 \mathrm{mM})$.
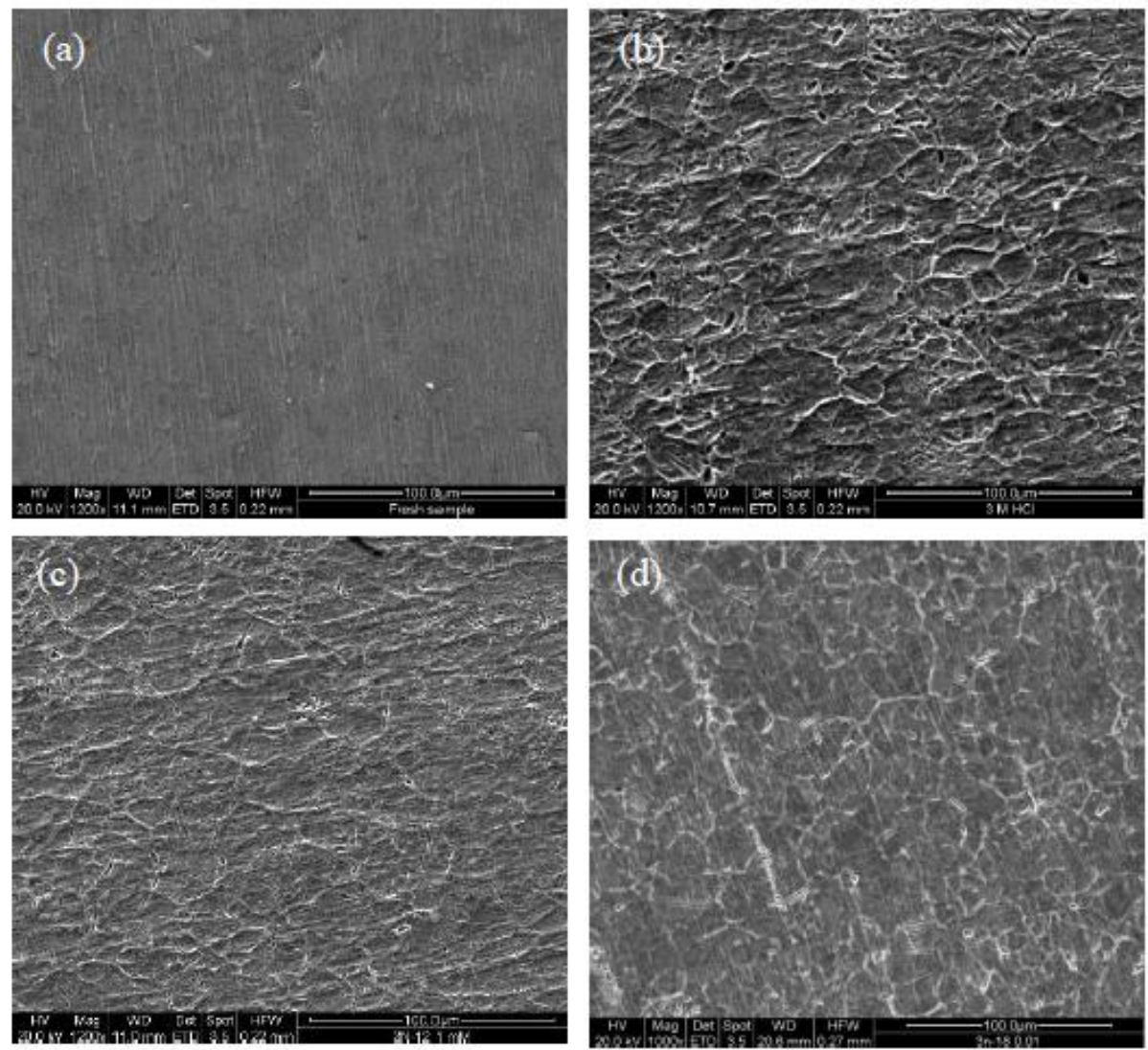
Table 1. Electrochemical polarisation parameters and inhibition efficiency (IE) for stainless steel in $3 \mathrm{M} \mathrm{HCl}$ in the absence and presence of different concentrations of inhibitors at room temperature.

\begin{tabular}{cccccccc} 
& $\begin{array}{c}\text { Concentration of the } \\
\text { surfactant }[\mathbf{m M}]\end{array}$ & $\begin{array}{c}\boldsymbol{E} \mathbf{~ v s} \mathbf{S C E} \\
{[\mathbf{m V}]}\end{array}$ & $\begin{array}{c}\boldsymbol{b}_{\boldsymbol{a}} \\
{[\mathbf{m V}]}\end{array}$ & $\begin{array}{c}\boldsymbol{b}_{\boldsymbol{c}} \\
{[\mathbf{m V}]}\end{array}$ & $\begin{array}{c}\boldsymbol{R}_{\boldsymbol{p}} \\
{\left[\mathbf{\Omega} \mathbf{c m}^{2}\right]}\end{array}$ & $\begin{array}{c}\boldsymbol{i}_{\text {corr }} \\
{\left[\boldsymbol{\mu} \mathbf{A c m}^{-2}\right]}\end{array}$ & $\begin{array}{c}\mathbf{I E} \\
{[\%]}\end{array}$ \\
\hline \multirow{3}{*}{$\mathbf{H C l}$} & 0 & -354.9 & 128 & 177 & 12.7 & 2550.0 & - \\
\hline \multirow{3}{*}{$\mathbf{3 N - 1 2}$} & 0.1 & -324.5 & 136 & 114 & 27.8 & 969.6 & 62 \\
& 0.5 & -327.1 & 135 & 135 & 87.7 & 334.6 & 87 \\
& 1 & -329.4 & 152 & 121 & 126.4 & 316.0 & 95 \\
& 2 & -328.2 & 194 & 133 & 225.6 & 152.1 & 94 \\
\hline \multirow{3}{*}{$\mathbf{3 N - 1 8}$} & 0.005 & -335.4 & 152 & 118 & 23.3 & 1238.0 & 50 \\
& 0.01 & -313.5 & 165 & 138 & 161.1 & 202.7 & 92 \\
& 0.05 & -330.2 & 181 & 118 & 41.3 & 751.6 & 70 \\
& 0.1 & -349.7 & 164 & 110 & 17.05 & 1687.8 & 36 \\
\hline
\end{tabular}


Table 2. EIS parameters for corrosion of stainless steel in $3 \mathrm{M} \mathrm{HCl}$ in absence and presence of different concentrations of the selected surfactants (after 24 hours).

\begin{tabular}{ccccccc} 
& $\begin{array}{c}\text { Concentration of } \\
\text { surfactant }[\mathbf{m M}]\end{array}$ & $\begin{array}{c}\boldsymbol{R}_{\boldsymbol{P}} \\
{\left[\boldsymbol{\Omega} \mathbf{c m}^{2}\right]}\end{array}$ & $\begin{array}{c}\boldsymbol{C}_{\boldsymbol{l - 1}} \\
{\left[\boldsymbol{\mu} \mathbf{F} / \mathbf{c m}^{2}\right]}\end{array}$ & $\begin{array}{c}\boldsymbol{C}_{l-2} \\
{\left[\boldsymbol{\mu} \mathbf{F} / \mathbf{c m}^{2}\right]}\end{array}$ & $\begin{array}{c}\mathbf{C R} \\
{[\mathbf{m m} / \mathbf{y e a r}]}\end{array}$ & $\begin{array}{c}\mathbf{I E} \\
{[\%]}\end{array}$ \\
\hline $3 \mathbf{3 M ~ H C l}$ & 0 & 18.86 & - & 4890 & 19.74 & - \\
\hline \multirow{3}{*}{$\mathbf{3 N - 1 2}$} & 0.1 & 48.28 & 1462 & 812 & 6.44 & 61 \\
& 0.5 & 138.16 & 810 & 278 & 2.45 & 86 \\
& 1 & 349.38 & 570 & 297 & 0.97 & 95 \\
& 2 & 301.87 & 531 & 200 & 1.31 & 94 \\
\hline \multirow{3}{*}{$\mathbf{3 N - 1 8}$} & 0.005 & 37.72 & 1894 & 1586 & 8.82 & 50 \\
& 0.01 & 211.42 & 403 & 268 & 1.78 & 91 \\
& 0.05 & 65.69 & 766 & 649 & 5.45 & 71 \\
& 0.1 & 25.92 & 2397 & 2261 & 12.73 & 27 \\
\hline
\end{tabular}


Table 3. Thermodynamic parameters of adsorption on stainless steel surface in $3 \mathrm{M} \mathrm{HCl}$ containing different concentrations of the corrosion inhibitors.

\begin{tabular}{ccccc} 
& $\mathbf{R}^{\mathbf{2}}$ & slope & $\begin{array}{c}\boldsymbol{K}_{\text {ads }} \\
{\left[\mathbf{M}^{\mathbf{1}}\right] \mathbf{x} \mathbf{~ 1 0}^{\mathbf{3}}}\end{array}$ & $\begin{array}{c}\Delta \boldsymbol{G}_{\text {ads }} \\
{\left[\mathbf{k J ~ m o l} \mathbf{~}^{\mathbf{1}}\right]}\end{array}$ \\
\hline $\mathbf{3 N - 1 2}$ & 0.9994 & 1.0307 & 20 & -34.49 \\
$\mathbf{3 N - 1 8}$ & 0.9924 & 1.3976 & 5000 & -48.17 \\
\hline
\end{tabular}


Table 4. The roughness of the stainless steel samples before and after ( 24 hours) immersion in $3 \mathrm{M} \mathrm{HCl}$ without and with tested corrosion inhibitors (the most efficient concentration).

\begin{tabular}{|c|c|c|c|c|}
\hline & $\begin{array}{c}\text { Before } \\
\text { immersion }\end{array}$ & $\begin{array}{l}\mathrm{HCl} \\
3 \mathrm{M}\end{array}$ & $\begin{array}{l}\mathrm{N}-12 \\
1 \mathrm{mM}\end{array}$ & $\begin{array}{c}\text { 3N-18 } \\
0.01 \mathrm{mM}\end{array}$ \\
\hline$R_{a}[\mu \mathrm{m}]$ & 2 & 5 & 2 & 4 \\
\hline
\end{tabular}



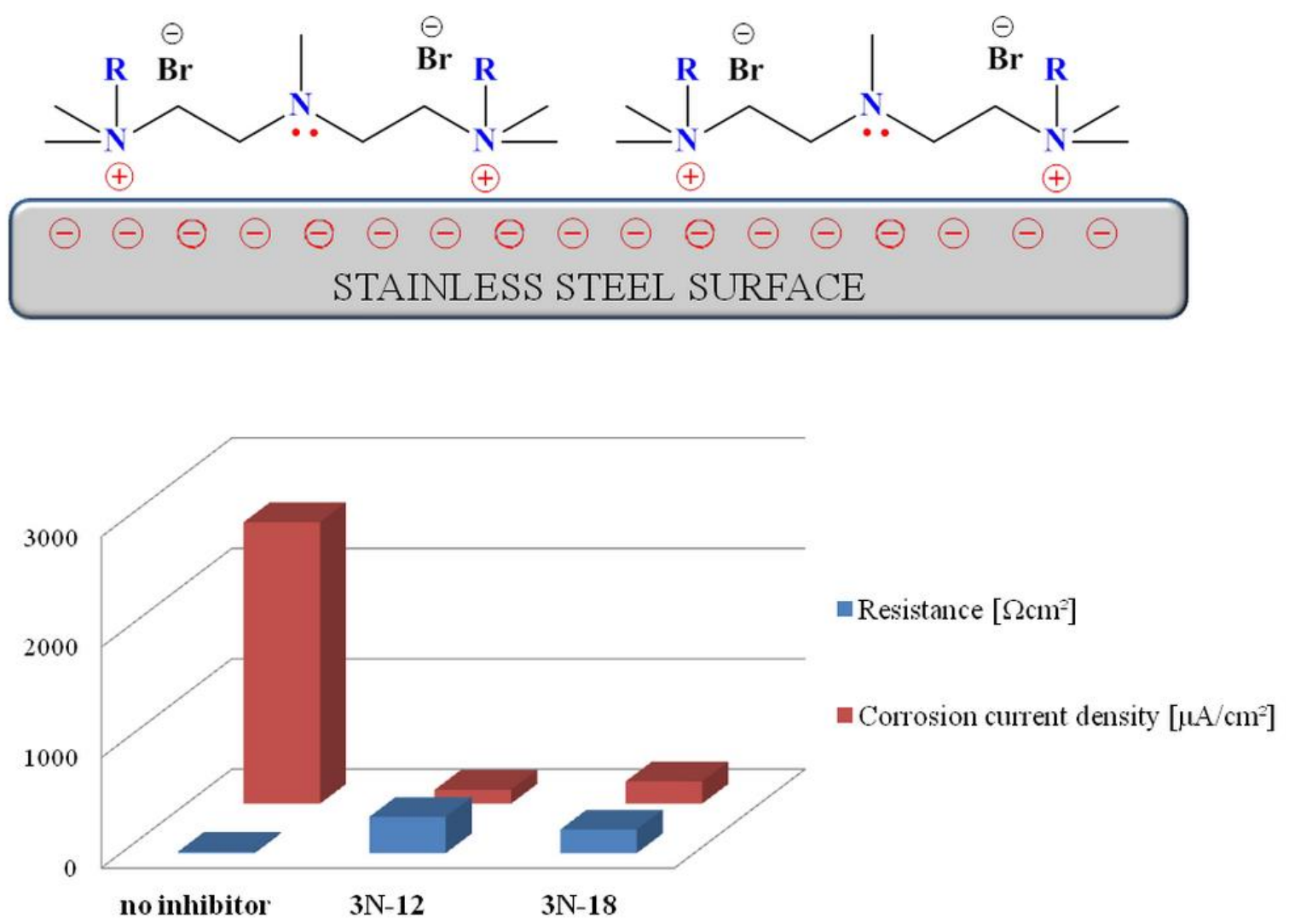

Graphical abstract 


\section{Highlights}

- Gemini surfactants with 3-azamethylpentamethylene spacer were studied as corrosion inhibitors

- Inhibition efficiency was investigated using electrochemical methods

- Adsorption follows a Langmuir adsorption isotherm model 